\title{
Supplementary Information for \\ The Me-TREN/TREN Mixed-Ligand Effect During SET-LRP in the Catalytically Active DMSO Revitalizes TREN Into an Excellent Ligand
}

\author{
Devendra S. Maurya, ${ }^{\dagger}$ Ayesha Malik,${ }^{\dagger}$ Xiaojing Feng, ${ }^{\dagger,} \star$ Nabil Bensabeh,${ }^{\S}$ \\ Gerard Lligadas, ${ }^{*, \uparrow}, \dagger$ and Virgil Percec ${ }^{*, \dagger}$
}

†Roy \& Diana Vagelos Laboratories, Department of Chemistry, University of Pennsylvania, Philadelphia, Pennsylvania 19104-6323, United States

tSchool of Chemistry and Biological Engineering, University of Science and Technology Beijing, Beijing 100083, China

${ }^{\S}$ Laboratory of Sustainable Polymers, Department of Analytical Chemistry and Organic Chemistry, University Rovira i Virgili, Tarragona 43007, Spain

\section{Table of Contents}

1. Kinetic Plots, Molecular Weight and Polydispersity Evolutions for the SET-LRP of MA .........S2

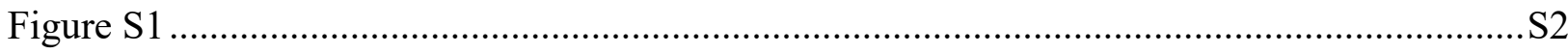

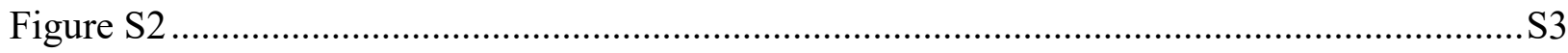

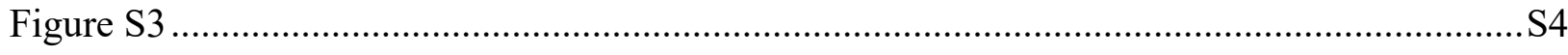

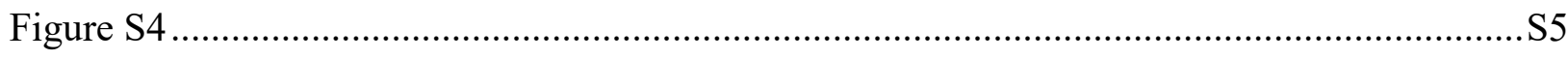

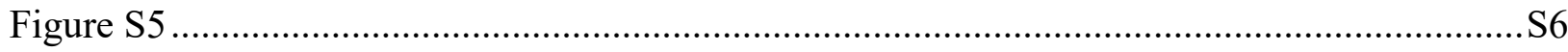

2. ${ }^{1} \mathrm{H}$ NMR and MALDI-TOF Spectra of PMA obtained by SET-LRP .............................................S7

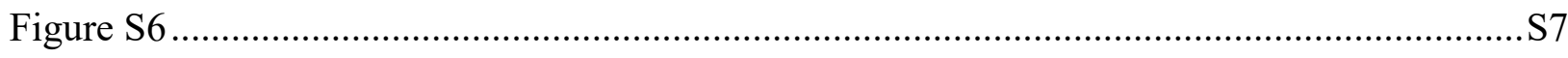

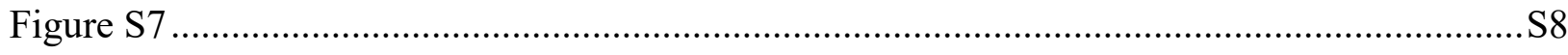

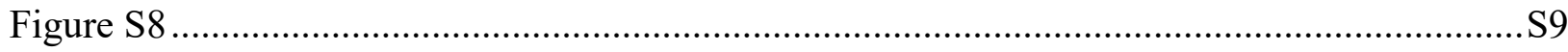

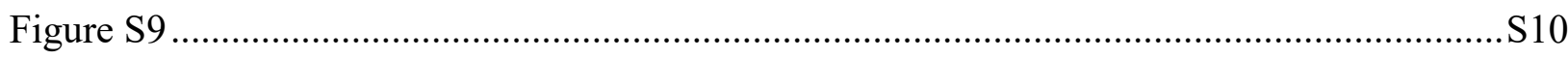

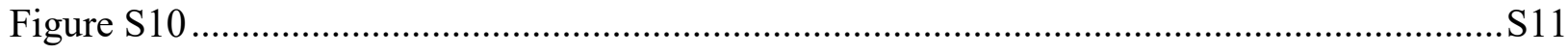



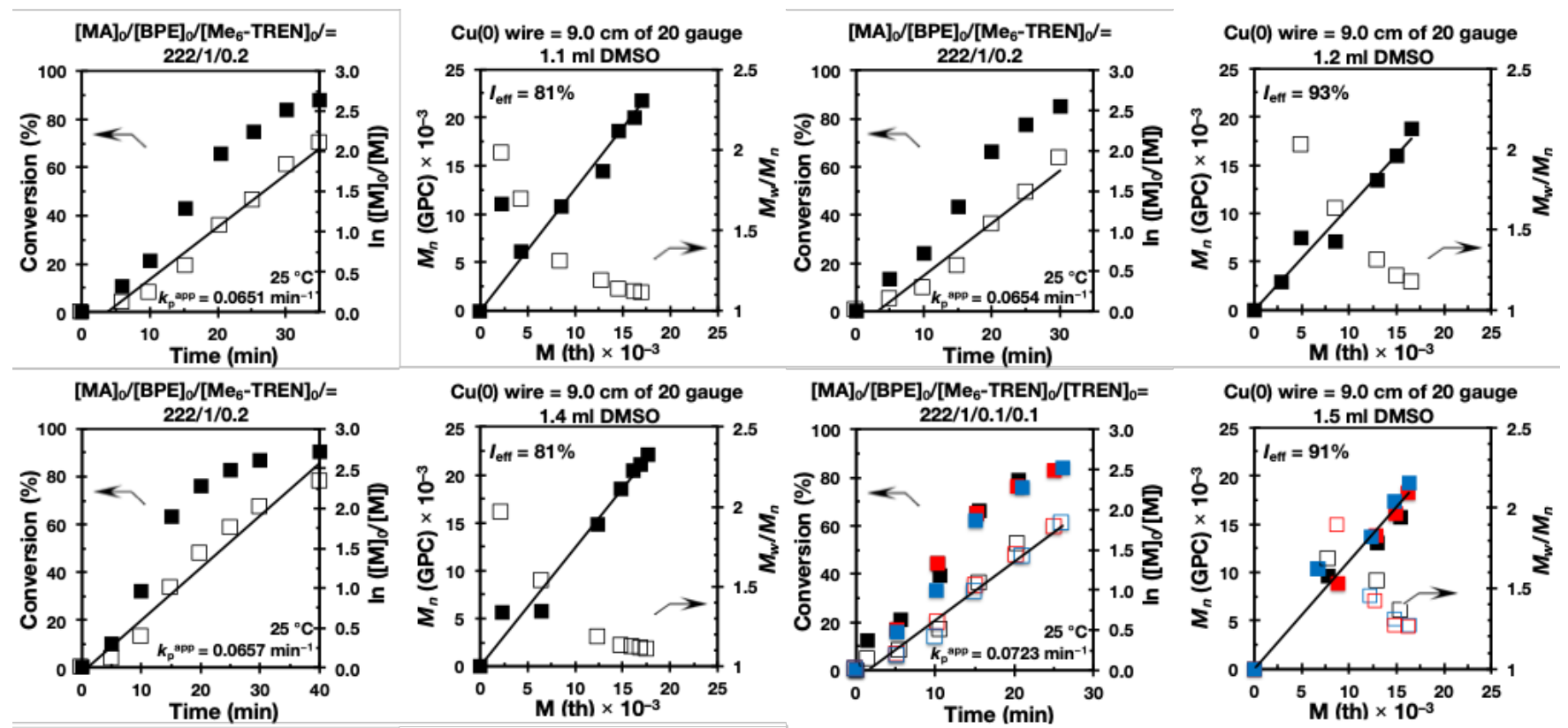

$\mathrm{Cu}(0)$ wire $=9.0 \mathrm{~cm}$ of 20 gauge
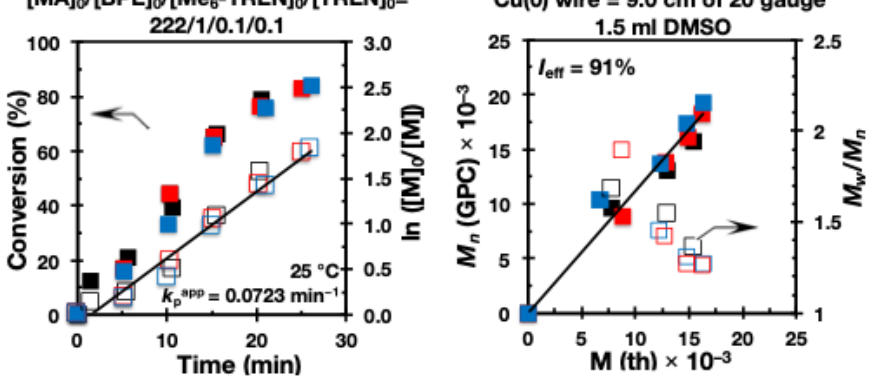

$[\mathrm{MA}]_{0} /[\mathrm{BPE}]_{0} /\left[\mathrm{Me}_{6}-\mathrm{TREN}_{0} /=\right.$
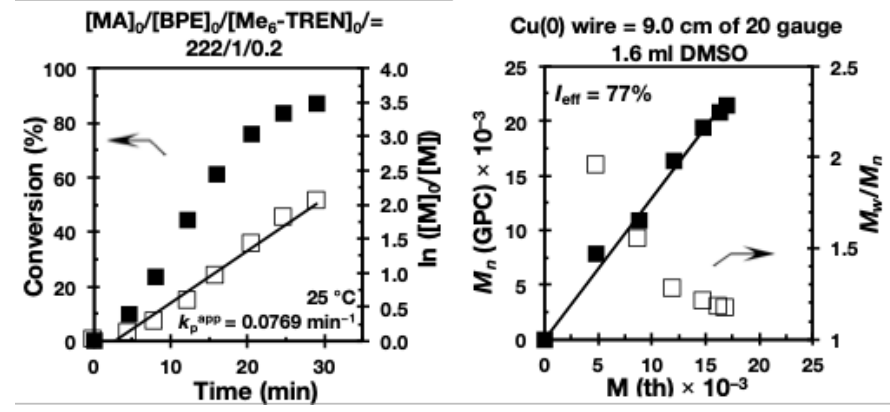

[MA $]_{0} /[\mathrm{BPE}]_{0} /\left[\mathrm{Me}_{6}-\mathrm{TREN}\right]_{0} /=$
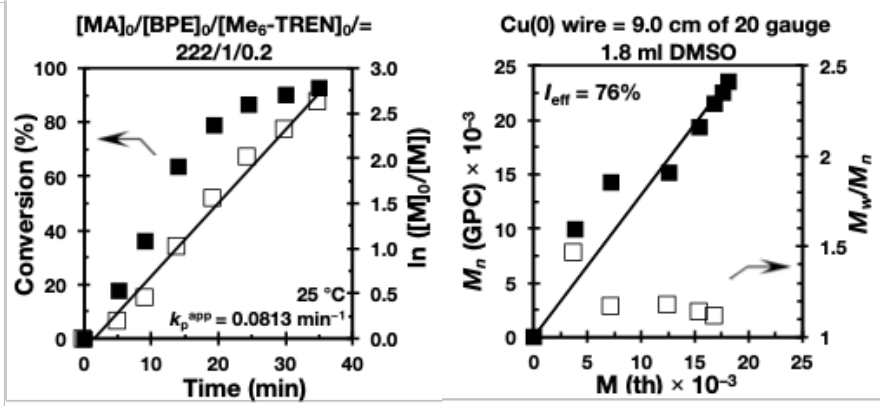

Figure S1. Kinetic plots, molecular weight and dispersity evolutions for the SET-LRP of MA in DMSO, initiated with BPE and catalyzed by $9.0 \mathrm{~cm}$ non-activated $\mathrm{Cu}(0)$ wire at $25^{\circ} \mathrm{C}$. Experimental data in different colors were obtained from different kinetics experiments, sometimes performed by different researchers. $k_{\mathrm{p}}^{\text {app }}$ and $I_{\text {eff }}$ are the average values of three experiments. $\ln \left(k_{\mathrm{p}}^{\text {app }}\right) v s \ln \left([\mathrm{DMSO}]_{0}\right)$, DMSO was varied from 1 to $1.8 \mathrm{~mL}$ with $2 \mathrm{~mL}$ of MA. $[\mathrm{MA}]_{0} /[\mathrm{BPE}]_{0} /\left[\mathrm{Me}_{6}-\mathrm{TREN}\right]_{0} /[\mathrm{Cu}(0)]_{0}=222 / 1 / 0.2 / 9 \mathrm{~cm}$. 

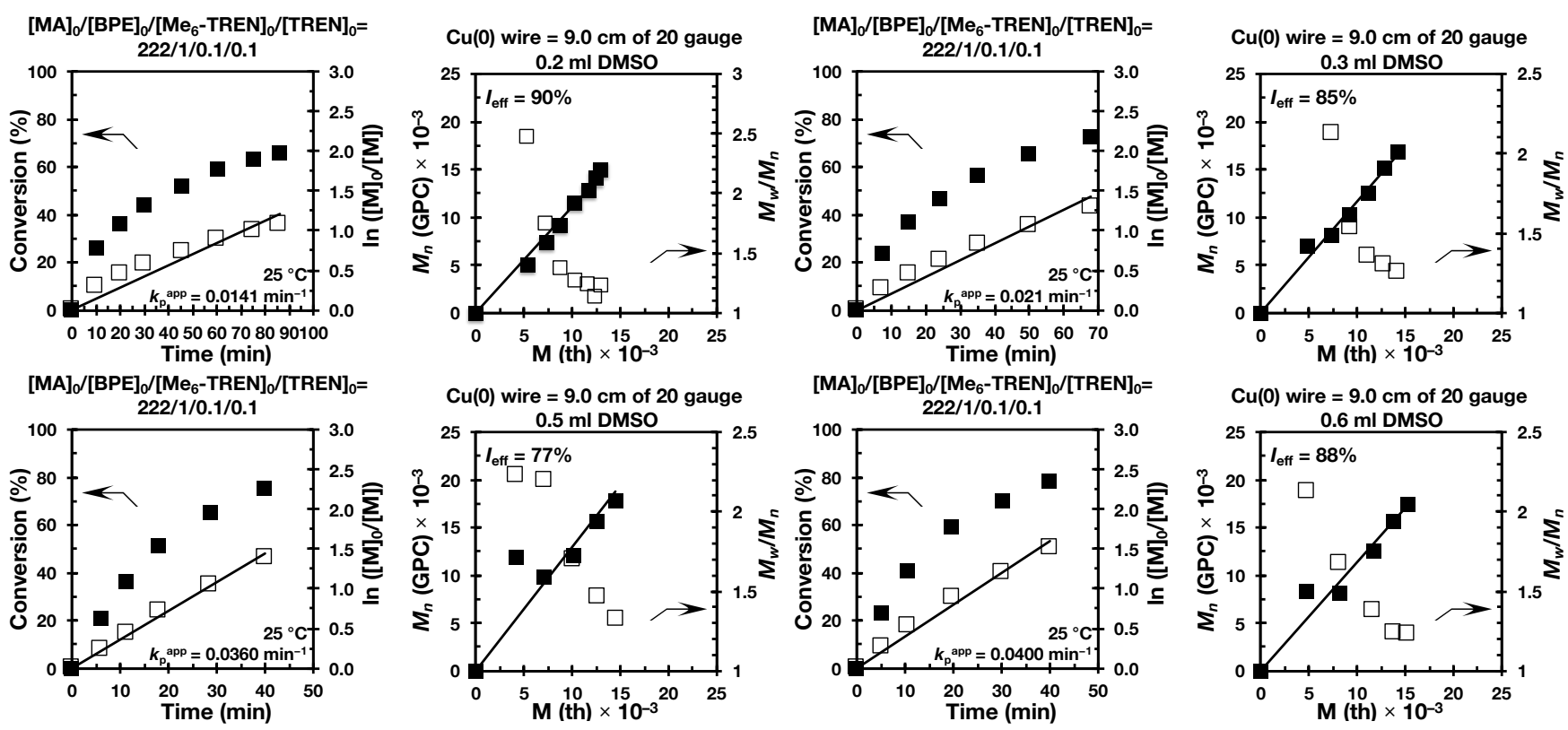

$\mathrm{Cu}(0)$ wire $=9.0 \mathrm{~cm}$ of 20 gauge
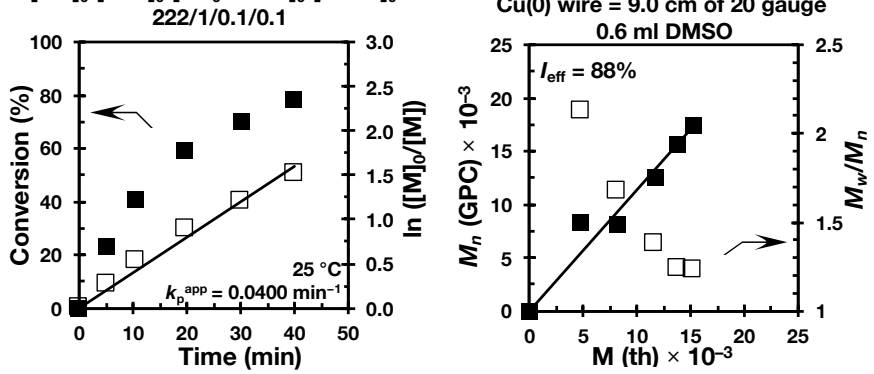

$[\mathrm{MA}]_{0} /[\mathrm{BPE}]_{0} /\left[\mathrm{Me}_{6}-\mathrm{TREN}\right]_{0} /[\mathrm{TREN}]_{0}=$
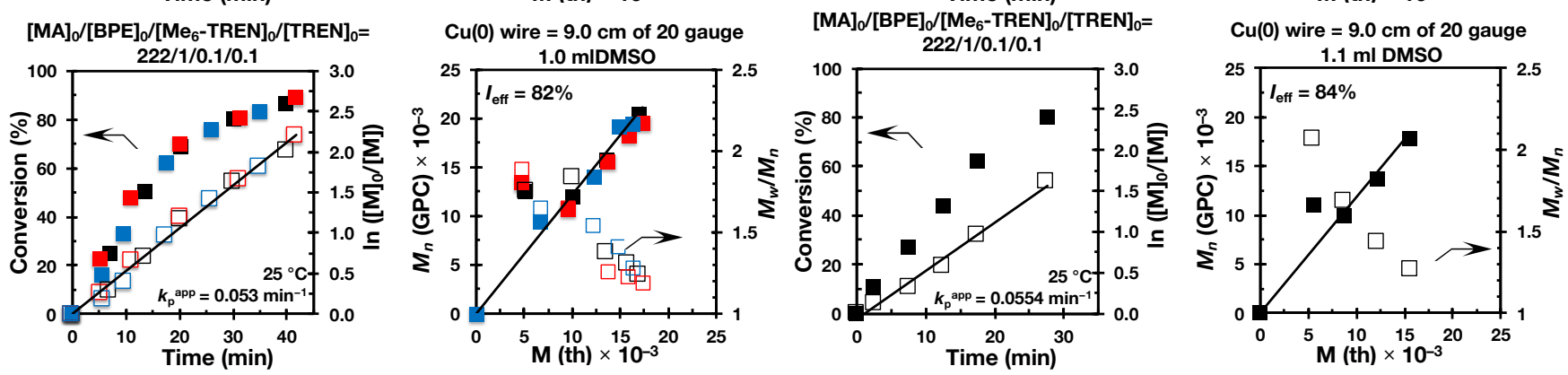

Figure S2. Kinetic plots, molecular weight and dispersity evolutions for the SET-LRP of MA in DMSO, initiated with $\mathrm{BPE}$ and catalyzed by $9.0 \mathrm{~cm}$ non-activated $\mathrm{Cu}(0)$ wire at $25{ }^{\circ} \mathrm{C}$. Experimental data in different colors were obtained from different kinetics experiments, sometimes performed by different researchers. $k_{\mathrm{p}}{ }^{\text {app }}$ and $I_{\text {eff }}$ are the average values of three experiments. $\ln \left(k_{\mathrm{p}}{ }^{\text {app }}\right) v s \ln \left([\mathrm{DMSO}]_{0}\right)$, DMSO was varied from 0.2 to $1.1 \mathrm{~mL}$ with $2 \mathrm{~mL}$ of MA. $[\mathrm{MA}]_{0} /[\mathrm{BPE}]_{0} /\left[\mathrm{Me}_{6}-\mathrm{TREN}\right]_{0} /[\mathrm{TREN}]_{0} /[\mathrm{Cu}(0)]_{0}=222 / 1 / 0.1 / 0.1 / 9 \mathrm{~cm}$. 

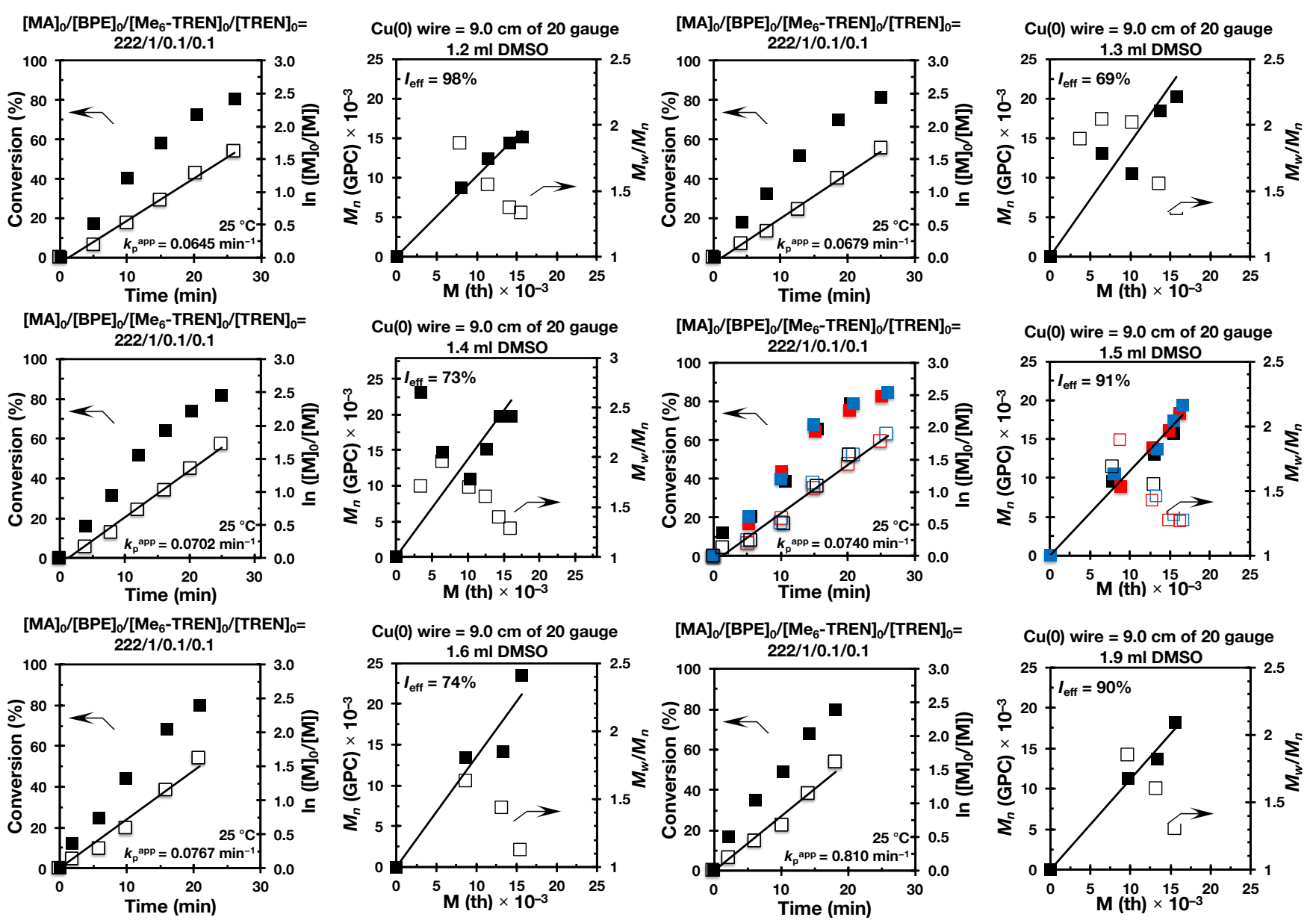

Figure S3. Kinetic plots, molecular weight and dispersity evolutions for the SET-LRP of MA in DMSO, initiated with BPE and catalyzed by $9.0 \mathrm{~cm}$ non-activated $\mathrm{Cu}(0)$ wire at $25^{\circ} \mathrm{C}$. Experimental data in different colors were obtained from different kinetics experiments, sometimes performed by different researchers. $k_{\mathrm{p}}{ }^{\text {app }}$ and $I_{\text {eff }}$ are the average value of three experiments. $\ln \left(k_{\mathrm{p}}{ }^{\mathrm{app}}\right) v_{\mathrm{s}} \ln \left([\mathrm{DMSO}]_{0}\right)$, DMSO was varied from 1.2 to $1.9 \mathrm{~mL}$ with 2 $\mathrm{mL}$ of MA. $[\mathrm{MA}]_{0} /[\mathrm{BPE}]_{0} /\left[\mathrm{Me}_{6}-\mathrm{TREN}\right]_{0} /[\mathrm{TREN}]_{0} /[\mathrm{Cu}(0)]_{0}=222 / 1 / 0.1 / 0.1 / 9 \mathrm{~cm}$. 


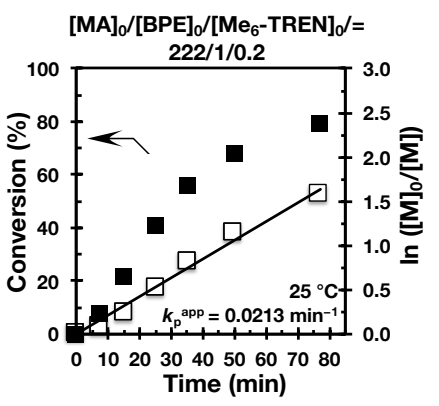

$[\mathrm{MA}]_{0} /[\mathrm{BPE}]_{0} /\left[\mathrm{Me}_{6}-\mathrm{TREN}_{0} /=\right.$

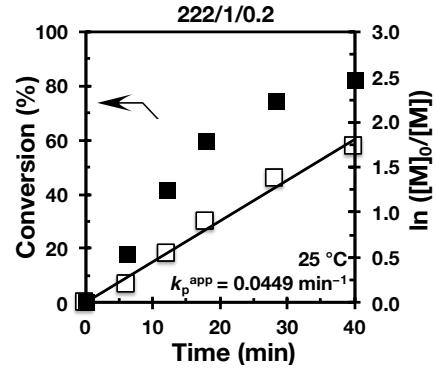

$[\mathrm{MA}]_{0} /[\mathrm{BPE}]_{0} /\left[\mathrm{Me}_{6}-\mathrm{TREN}_{0} /=\right.$

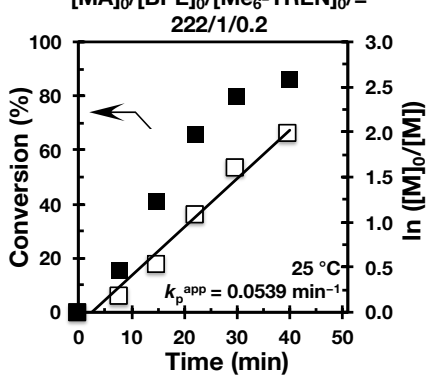

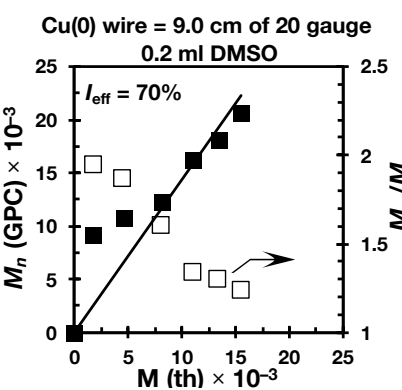

$\mathrm{Cu}(0)$ wire $=9.0 \mathrm{~cm}$ of 20 gauge

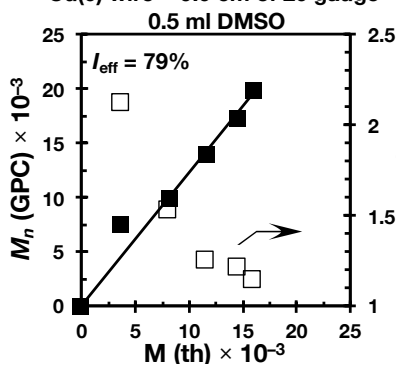

$\mathrm{Cu}(0)$ wire $=9.0 \mathrm{~cm}$ of 20 gauge

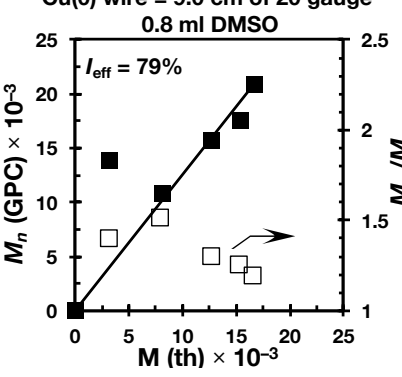

$[\mathrm{MA}]_{0} /[\mathrm{BPE}]_{0} /\left[\mathrm{Me}_{6}-\mathrm{TREN}\right]_{0} /=$

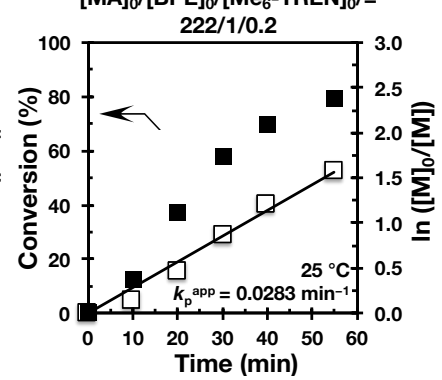

$[\mathrm{MA}]_{0} /[\mathrm{BPE}]_{0} /\left[\mathrm{Me}_{6}-\mathrm{TREN}_{0} /=\right.$

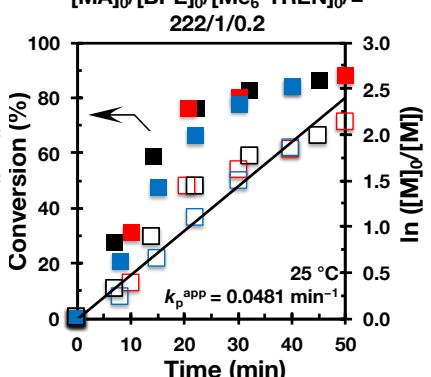

$[\mathrm{MA}]_{0} /[\mathrm{BPE}]_{0} /\left[\mathrm{Me}_{6}-\mathrm{TREN}\right]_{0} /=$

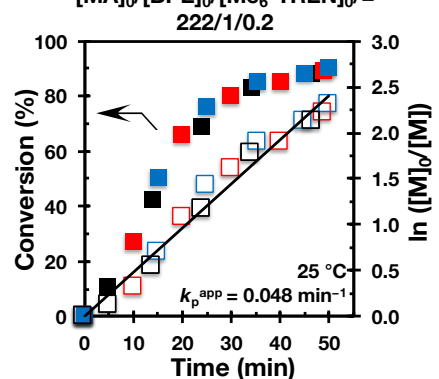

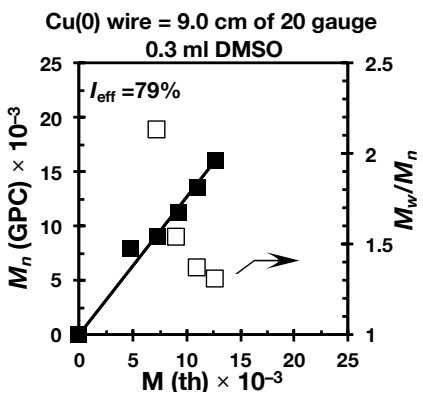

$\mathrm{Cu}(0)$ wire $=9.0 \mathrm{~cm}$ of 20 gauge

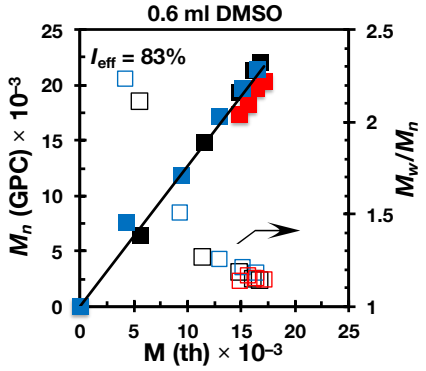

$\mathrm{Cu}(0)$ wire $=9.0 \mathrm{~cm}$ of 20 gauge

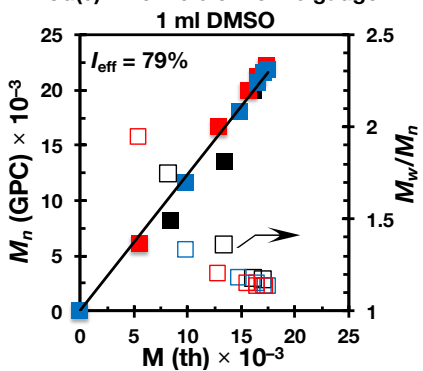

Figure S4. Kinetic plots, molecular weight and dispersity evolutions for the SET-LRP of MA in DMSO initiated with BPE and catalyzed with $9.0 \mathrm{~cm}$ non-activated $\mathrm{Cu}(0)$ wire at $25^{\circ} \mathrm{C}$. Experimental data in different colors were obtained from different kinetics experiments, sometimes performed by different researchers. $k_{\mathrm{p}}{ }^{\text {app }}$ and $I_{\text {eff }}$ are the average values of three experiments. $k_{\mathrm{p}}^{\text {app }} v s[\mathrm{DMSO}]_{0}$ with DMSO varied from 0.2 to $1 \mathrm{~mL}$ with $2 \mathrm{~mL}$ of MA. $[\mathrm{MA}]_{0} /[\mathrm{BPE}]_{0} /\left[\mathrm{Me}_{6}-\mathrm{TREN}\right]_{0} /[\mathrm{Cu}(0)]_{0}=222 / 1 / 0.2 / 9 \mathrm{~cm}$. 


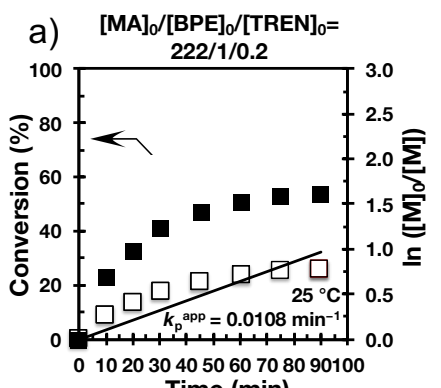

c)

$$
\text { Time (min) }
$$

$[\mathrm{MA}]_{0} /[\mathrm{BPE}]_{0} /[\mathrm{TREN}]_{0}=$

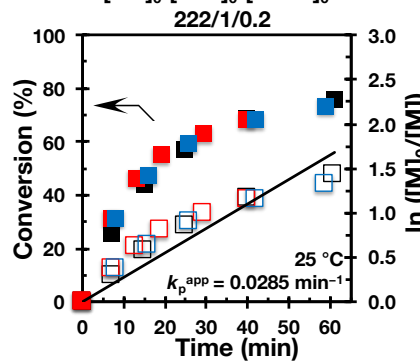

e) $[\mathrm{MA}]_{0} /[\mathrm{BPE}]_{0} /[\mathrm{TREN}]_{0}=$

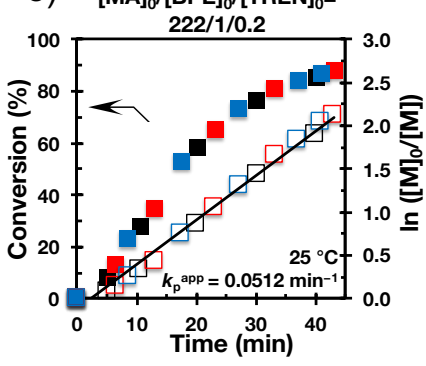

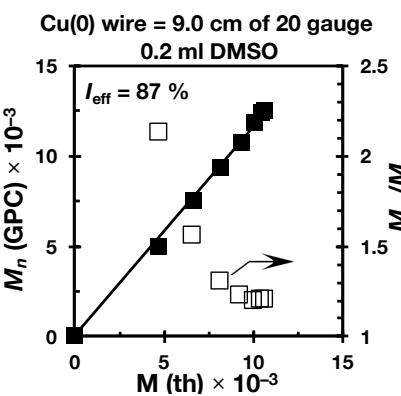

$\mathrm{Cu}(0)$ wire $=9.0 \mathrm{~cm}$ of 20 gauge
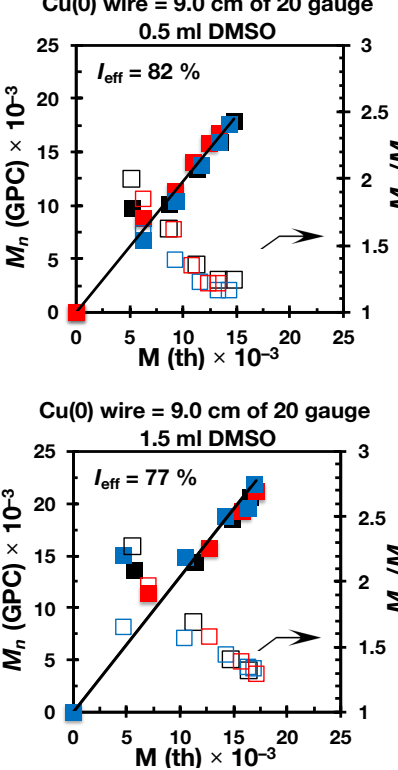

b) $[\mathrm{MA}]_{0} /[\mathrm{BPE}]_{0} /[\mathrm{TREN}]_{0}=$

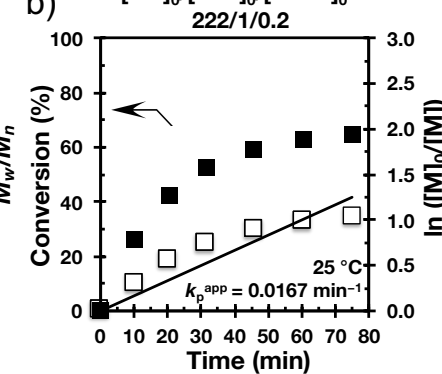

Time (min)

d)

$[\mathrm{MA}]_{0} /[\mathrm{BPE}]_{0} /[\mathrm{TREN}]_{0}=$

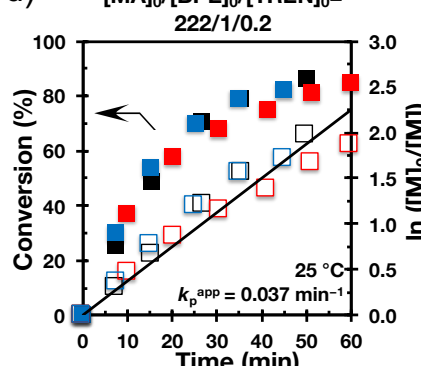

f)

$[\mathrm{MA}]_{0} /[\mathrm{BPE}]_{0} /[\mathrm{TREN}]_{0}=$

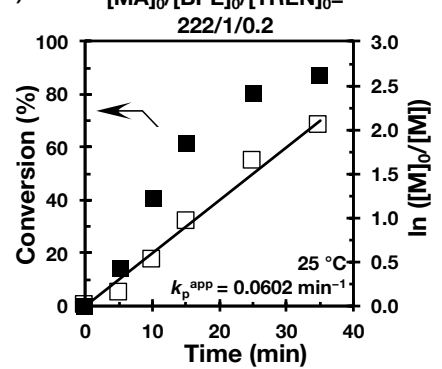

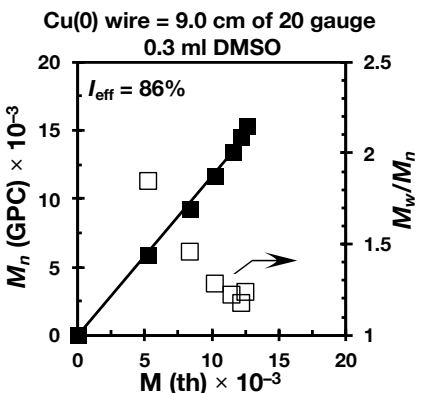

$\mathrm{Cu}(0)$ wire $=9.0 \mathrm{~cm}$ of 20 gauge

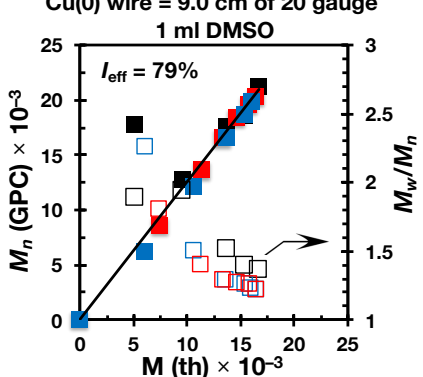

$\mathrm{Cu}(0)$ wire $=9.0 \mathrm{~cm}$ of 20 gauge

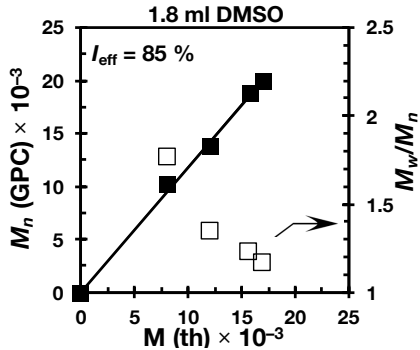

Figure S5. Kinetic plots, molecular weight and dispersity evolutions for the SET-LRP of MA in DMSO initiated with $\mathrm{BPE}$ and catalyzed with $9.0 \mathrm{~cm}$ non-activated $\mathrm{Cu}(0)$ wire at $25^{\circ} \mathrm{C}$. Experimental data in different colors were obtained from different kinetics experiments, some times performed by different researchers. $k_{p}^{a p p}$ and $I^{\text {eff }}$ are the average values of three experiments. $k_{p}^{a p p}$ vs $[\mathrm{DMSO}]_{0}$ with DMSO varied from 0.2 to $1.8 \mathrm{~mL}$ with $2 \mathrm{~mL}$ of MA. $[\mathrm{MA}]_{0} /[\mathrm{BPE}]_{0} /[\mathrm{TREN}]_{0} /[\mathrm{Cu}(0)]_{0}=222 / 1 / 0.2 / 9 \mathrm{~cm}$. 


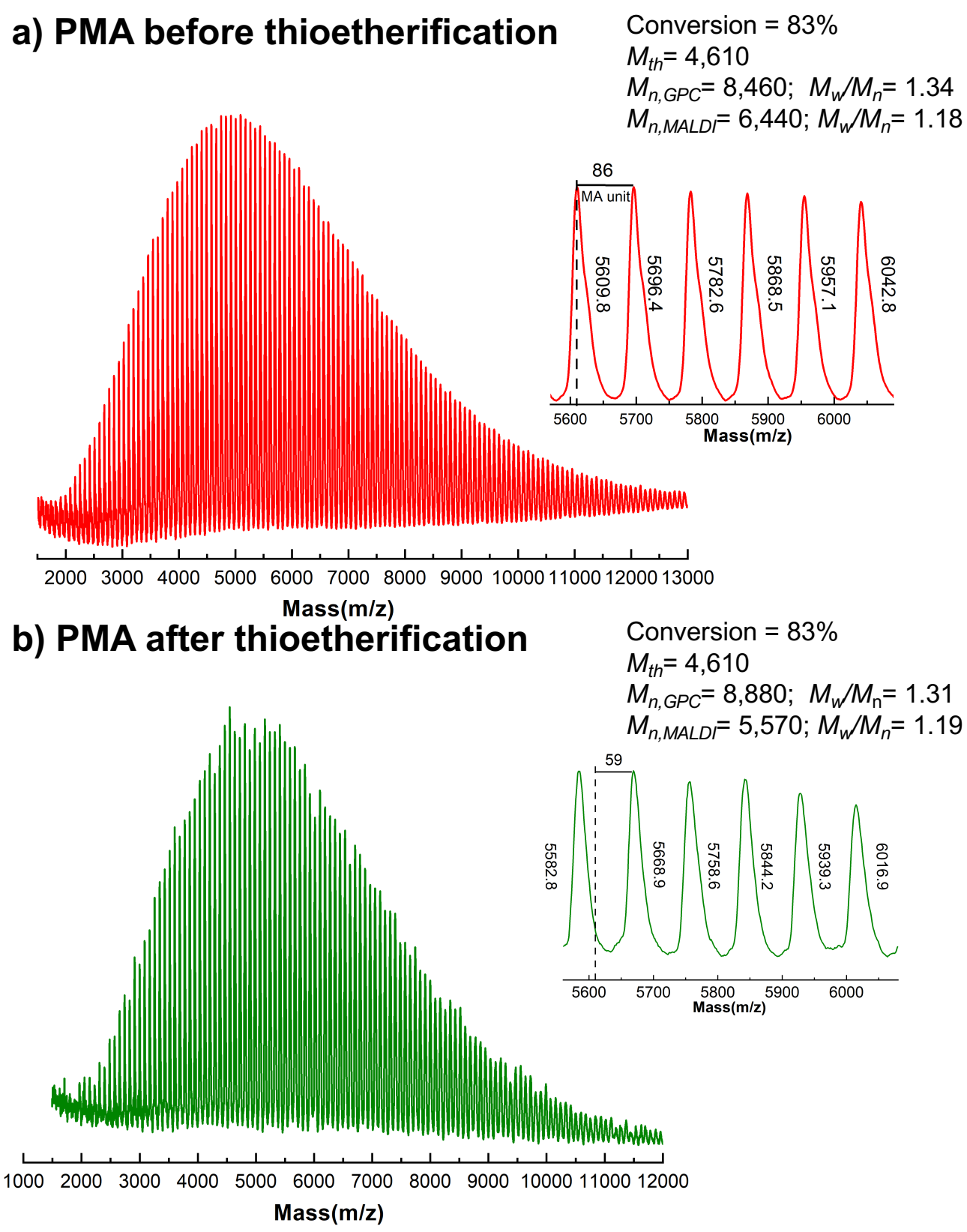

Figure S6. MALDI-TOF of PMA-Br isolated at $83 \%$ from SET-LRP of MA in DMSO solution initiated with BPE and catalyzed by non-activated $\mathrm{Cu}(0)$ wire at $25{ }^{\circ} \mathrm{C}$; (a) before thio-bromo "click" reaction; (b) after thiobromo "click" reaction. Reaction conditions: $\mathrm{MA}=2 \mathrm{~mL}, \mathrm{DMSO}=1.50 \mathrm{~mL},[\mathrm{MA}]_{0} /[\mathrm{BPE}]_{0} /\left[\mathrm{Me}_{6}-\mathrm{TREN}\right]_{0}=$ $60 / 1 / 0.2,9.0 \mathrm{~cm}$ of 20 gauge $\mathrm{Cu}(0)$ wire. The dotted line in expansion after thioeterification shows the original peak from before thioeterification, while 59 represents the increase in molar mass after thioeterification i.e., $2 *[\mathrm{SC} 6 \mathrm{H} 5(109,2)-\mathrm{Br}(79,9)]=58.57$ for each chain end. 

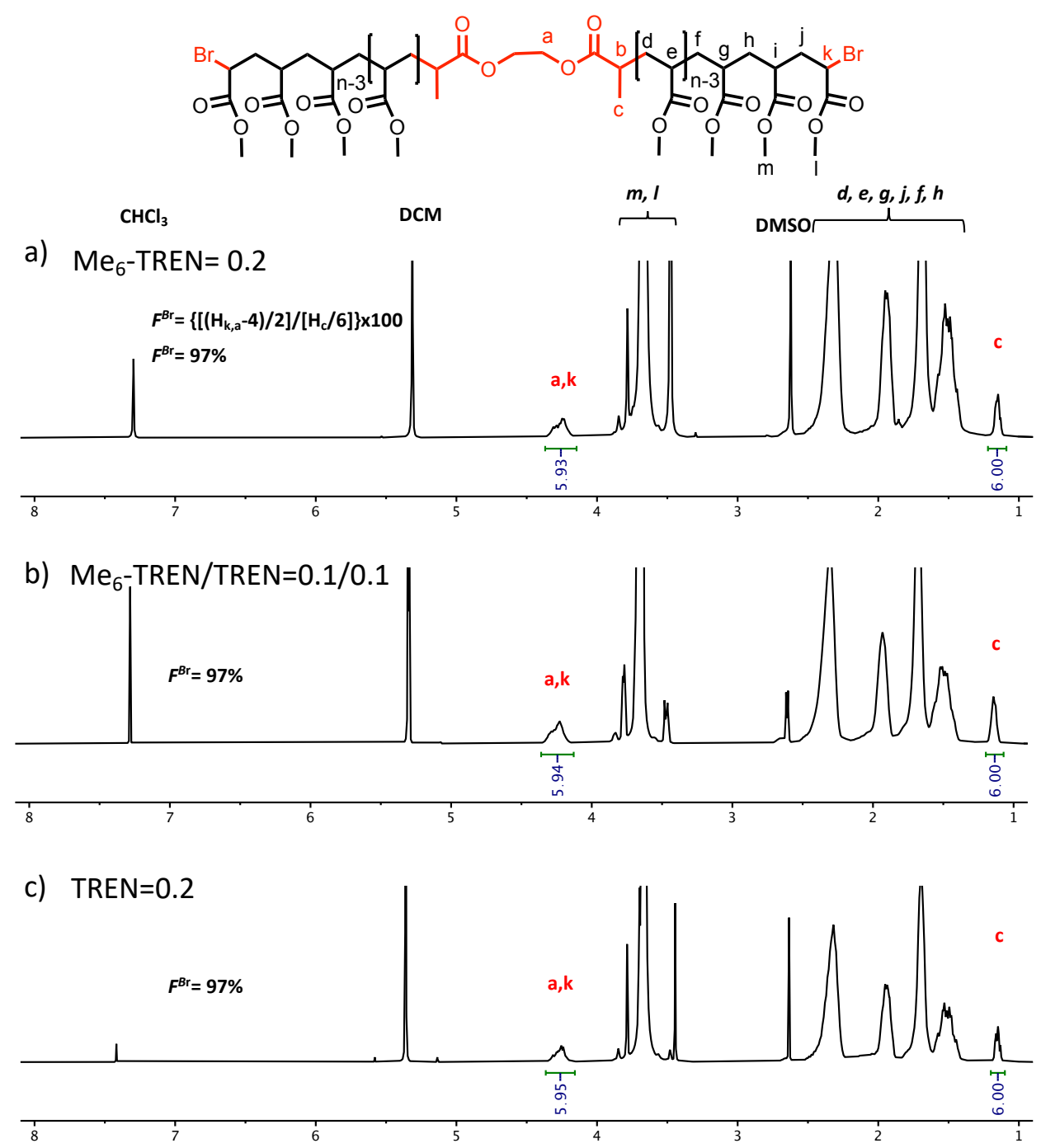

Figure S7. ${ }^{1} \mathrm{H}$ NMR spectra at $400 \mathrm{MHz}$ of $\alpha, \omega$-di(bromo)PMA at: (a) $83 \%$ conversion $\left(M_{n}=8,460\right.$ and $M_{w} / M_{n}=$ 1.34), $\quad\left([\mathrm{MA}]_{0} /[\mathrm{BPE}]_{0} /\left[\mathrm{Me}_{6}-\mathrm{TREN}\right]_{0}=60 / 1 / 0.2\right)$; (b) $92 \%$ conversion $\left(M_{n}=6,420\right.$ and $\left.M_{w} / M_{n}=1.27\right)($ $\left.[\mathrm{MA}]_{0} /[\mathrm{BPE}]_{0} /\left[\mathrm{Me}_{6}-\mathrm{TREN}\right]_{0} /[\mathrm{TREN}]_{0}=60 / 1 / 0.1 / 0.1\right)$; (c) $95 \%$ conversion $\left(M_{n}=7,690\right.$ and $\left.M_{w} / M_{n}=1.15\right)($ $\left.[\mathrm{MA}]_{0} /[\mathrm{BPE}]_{0} /[\mathrm{TREN}]_{0}=60 / 1 / 0.2\right)$; Polymerization conditions: $\mathrm{MA}=2 \mathrm{~mL}, \mathrm{DMSO}=1.5 \mathrm{~mL}$ and non-activated $9 \mathrm{~cm} \mathrm{Cu}(0)$ wire of 20 gauge. The signals at $7.26 \mathrm{ppm}$ and $5.30 \mathrm{ppm}$ are due to the partially non-deuterated residues of $\mathrm{CDCl}_{3}$ and dichloromethane, respectively. 


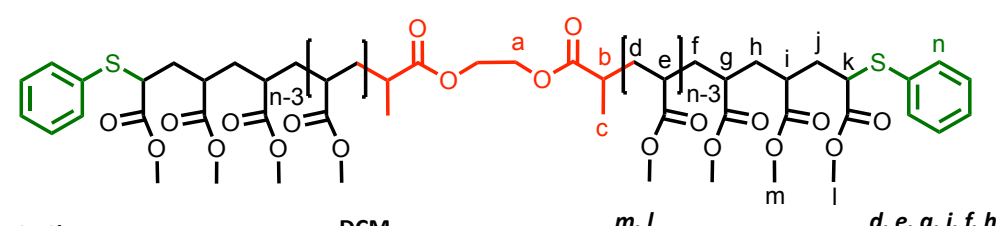

$\mathrm{CHCl}_{3} \quad \mathrm{DCM}$

$m, l$

$d, e, g, j, f, h$

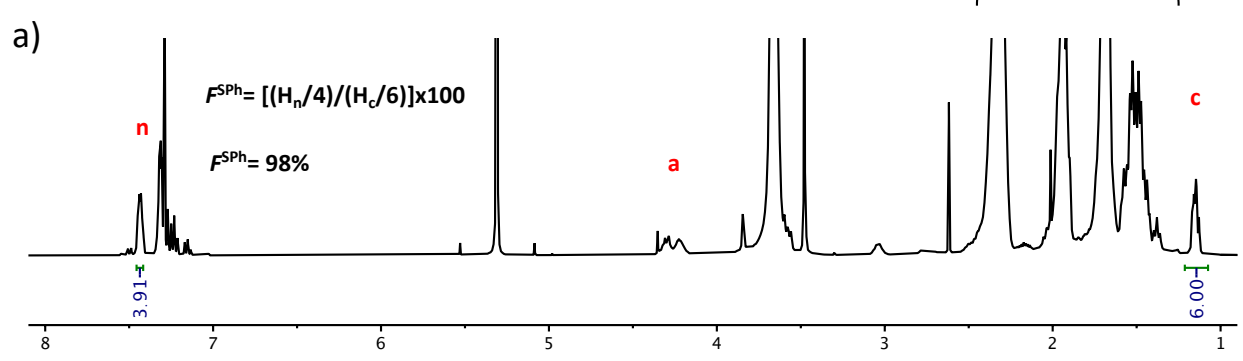

b)

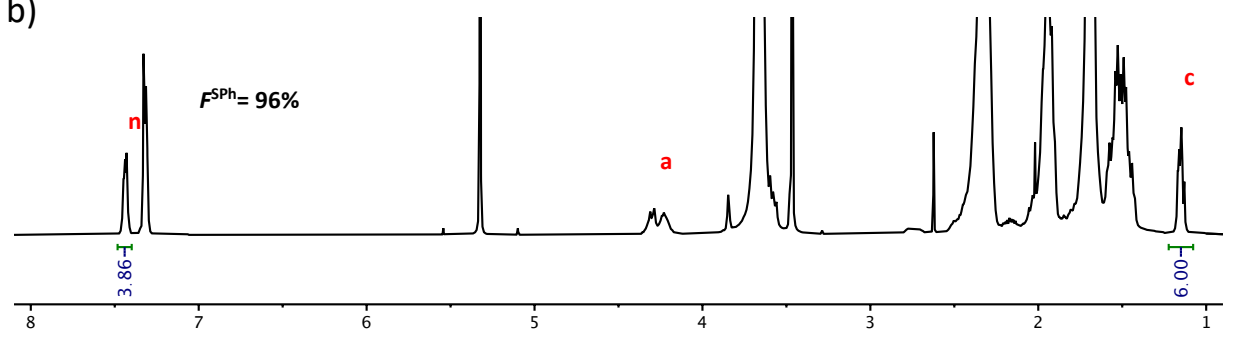

c)

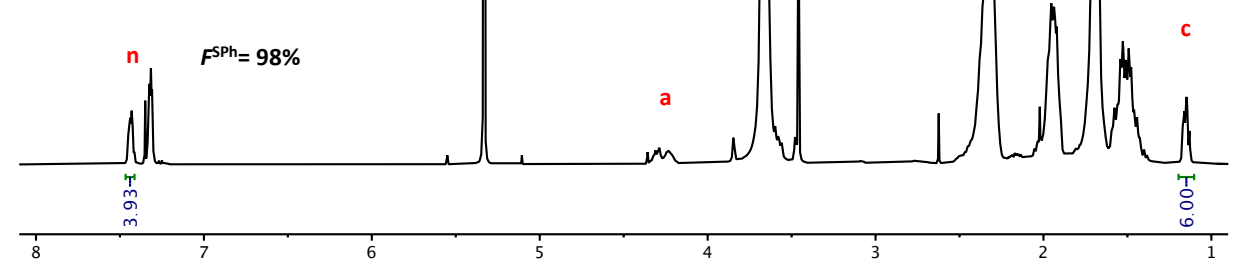

Figure S8. ${ }^{1} \mathrm{H}$ NMR spectra at $400 \mathrm{MHz}$ of $\alpha, \omega$-di(phenylthio)PMA at: (a) $83 \%$ conversion $\left(M_{n}=8,880\right.$ and $\left.M_{w} / M_{n}=1.19\right), \quad\left([\mathrm{MA}]_{0} /[\mathrm{BPE}]_{0} /\left[\mathrm{Me}_{6}-\mathrm{TREN}\right]_{0}=60 / 1 / 0.2\right) ;\left(\right.$ b) $90 \%$ conversion $\left(M_{n}=7,140\right.$ and $M_{w} / M_{n}=$ 1.27), ( $\left.[\mathrm{MA}]_{0} /[\mathrm{BPE}]_{0} /\left[\mathrm{Me}_{6}-\mathrm{TREN}\right]_{0} /[\mathrm{TREN}]_{0}=60 / 1 / 0.1 / 0.1\right)$; (c) $96 \%$ conversion $\left(M_{n}=8,180\right.$ and $M_{w} / M_{n}=1.13$ ),$\left([\mathrm{MA}]_{0} /[\mathrm{BPE}]_{0} /[\mathrm{TREN}]_{0}=60 / 1 / 0.2\right)$; Polymerization conditions: $\mathrm{MA}=2 \mathrm{~mL}, \mathrm{DMSO}=1.5 \mathrm{~mL}$ and nonactivated $9 \mathrm{~cm} \mathrm{Cu}(0)$ wire of 20 gauge. The signals at $7.26 \mathrm{ppm}$ and $5.30 \mathrm{ppm}$ are due to the partially nondeuterated residues of $\mathrm{CDCl}_{3}$ and dichloromethane, respectively. 


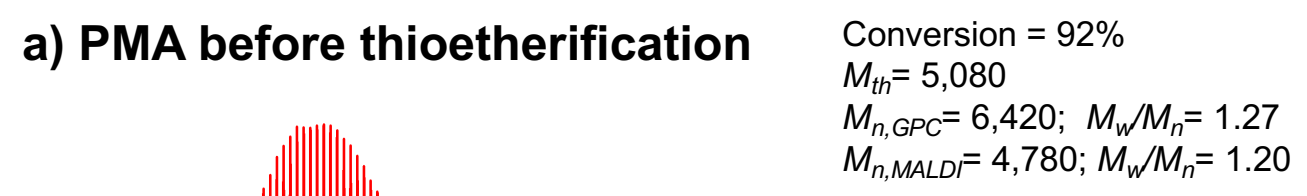

Conversion $=92 \%$

$M_{t h}=5,080$

$M_{n, G P C}=6,420 ; M_{w} / M_{n}=1.27$

86

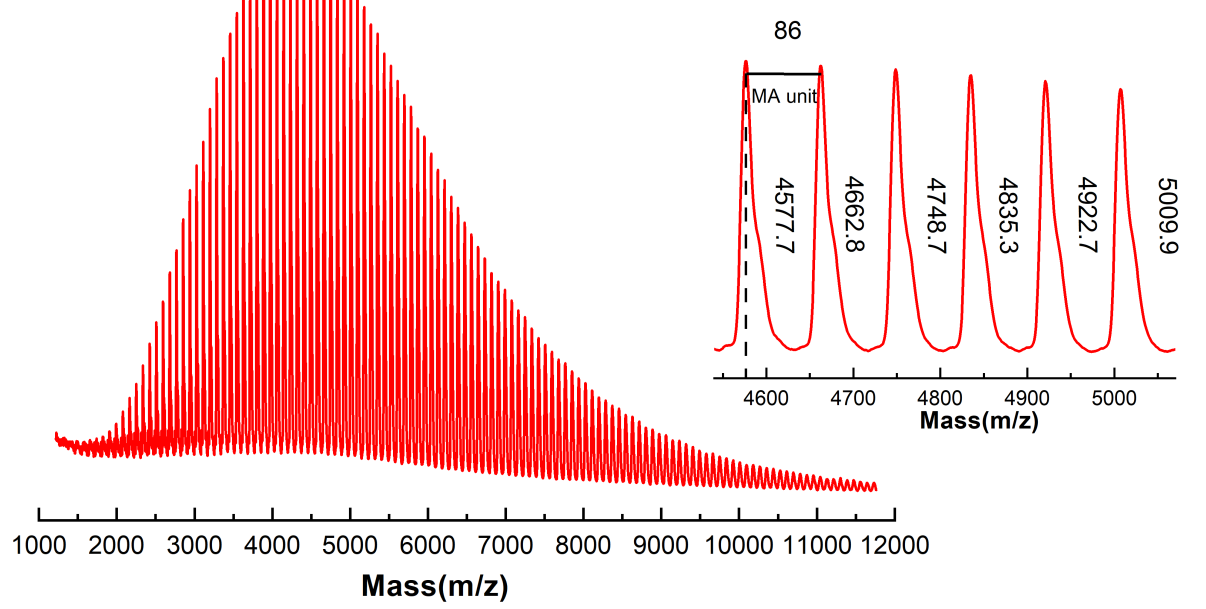

b) PMA after thioetherification

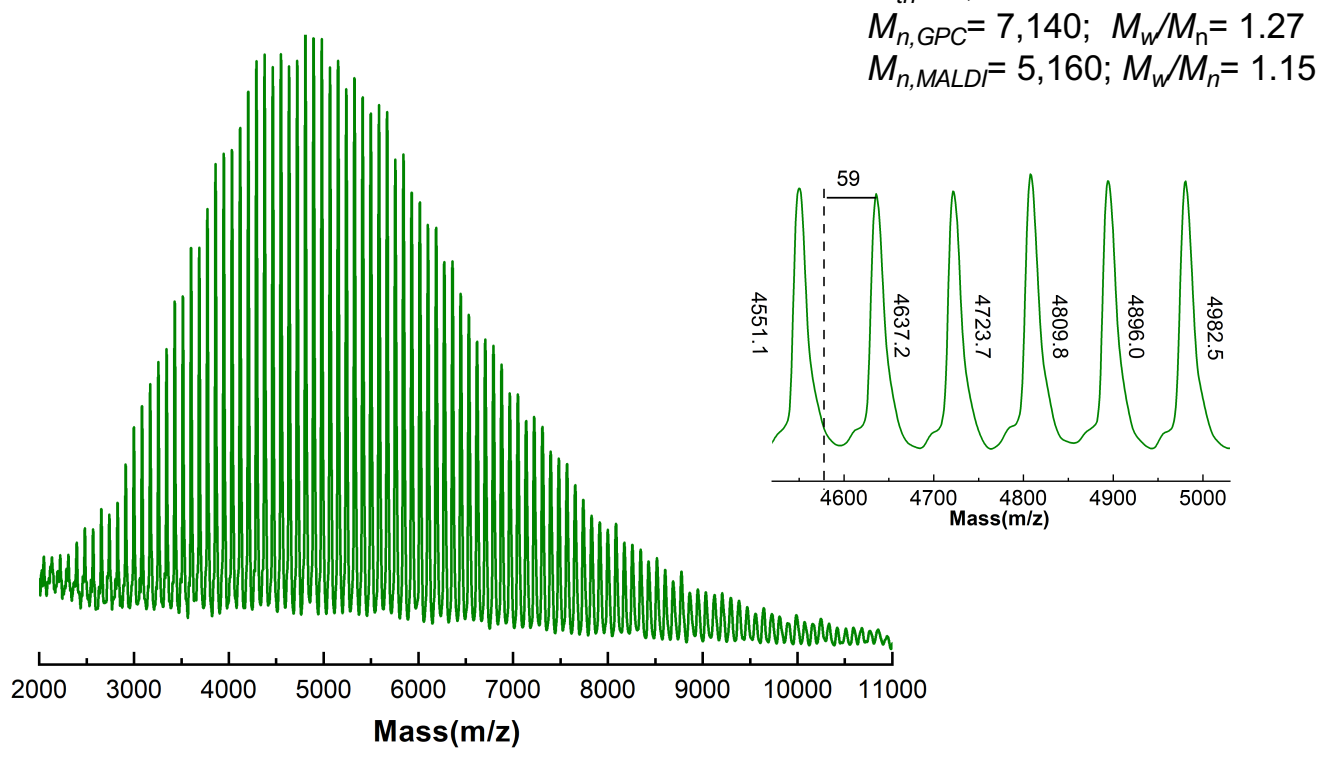

Figure S9. MALDI-TOF of PMA-Br isolated at $92 \%$ from SET-LRP of MA in DMSO solution initiated with $\mathrm{BPE}$ and catalyzed by non-activated $\mathrm{Cu}(0)$ wire at $25^{\circ} \mathrm{C}$; (a) before thio-bromo "click" reaction; (b) After thiobromo "click" reaction. Reaction conditions: $\mathrm{MA}=2 \mathrm{~mL}$, DMSO $=1.50 \mathrm{~mL},[\mathrm{MA}]_{0} /[\mathrm{BPE}]_{0} /\left[\mathrm{Me}_{6}-\mathrm{TREN}_{0}\right.$ $/[\mathrm{TREN}]_{0}=60 / 1 / 0.1 / 0.1,9.0 \mathrm{~cm}$ of 20 gauge $\mathrm{Cu}(0)$ wire. The dotted line in expansion after thioeterification shows the original peak from before thioeterification, while 59 represents the increase in molar mass after thioeterification i.e., $2 *[\mathrm{SC} 6 \mathrm{H} 5(109,2)-\mathrm{Br}(79,9)]=58.57$ for each chain end. 


\section{a) PMA before thioetherification}

Conversion $=95 \%$

$M_{t h}=5,230$

$M_{n, G P C}=7,690 ; M_{w} / M_{n}=1.14$

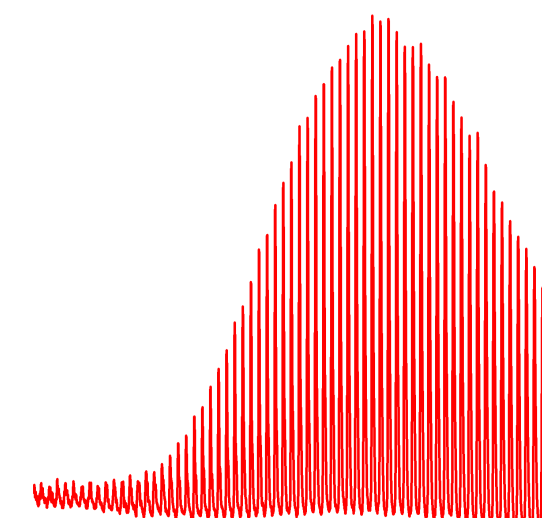

$M_{n, M A L D I}=5,620 ; M_{w} / M_{n}=1.15$

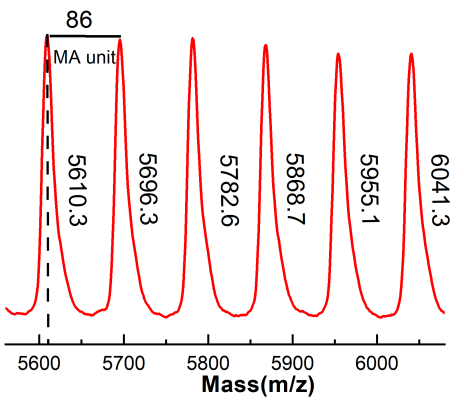

nunumunum
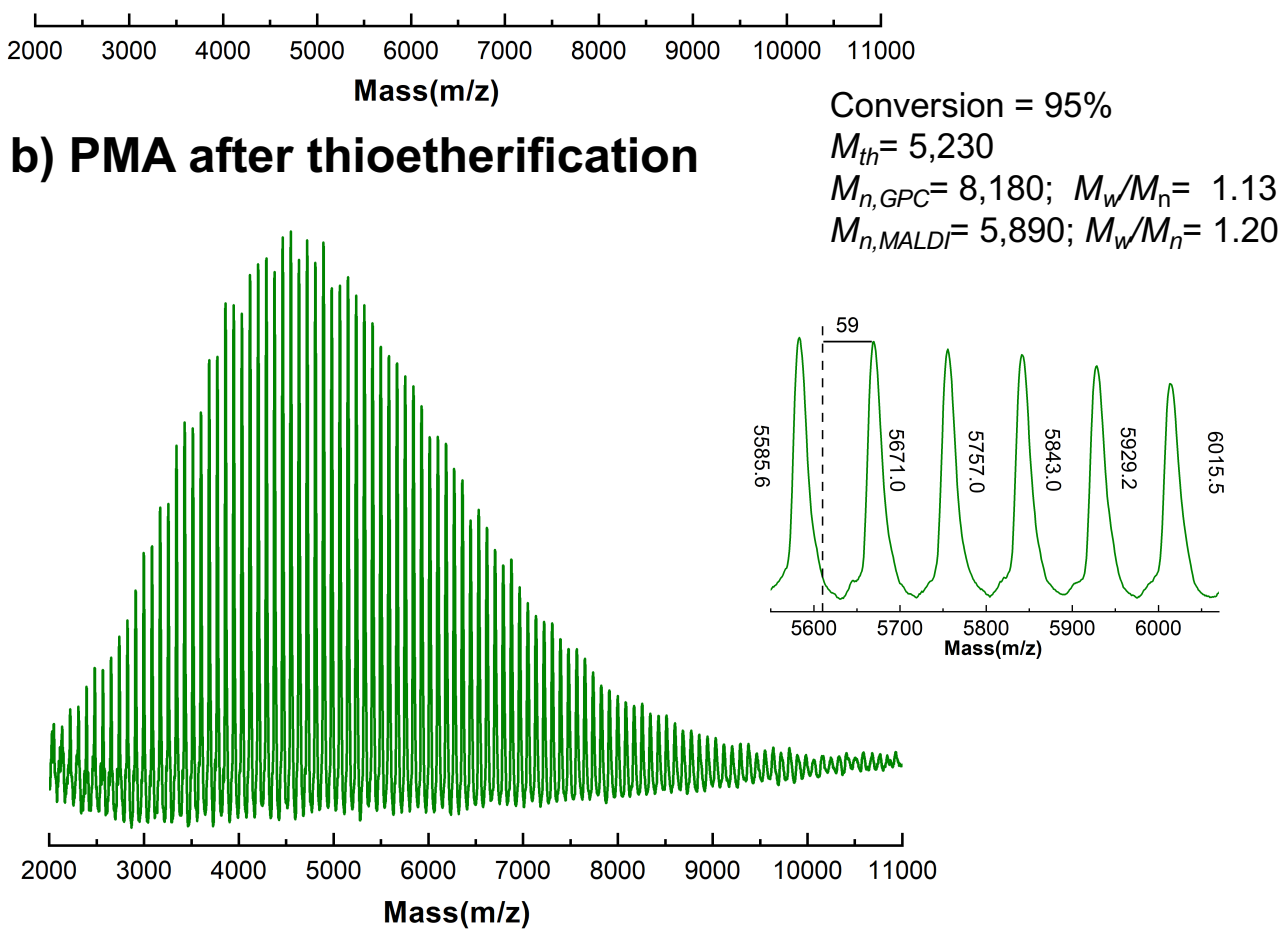

Figure S10. MALDI-TOF of PMA-Br isolated at $95 \%$ from SET-LRP of MA in DMSO solution initiated with $\mathrm{BPE}$ and catalyzed by non-activated $\mathrm{Cu}(0)$ wire at $25^{\circ} \mathrm{C}$; (a) before thio-bromo "click" reaction; (b) after thiobromo "click" reaction. Reaction conditions: $\mathrm{MA}=2 \mathrm{~mL}, \mathrm{DMSO}=1.50 \mathrm{~mL},[\mathrm{MA}]_{0} /[\mathrm{BPE}]_{0} /[\mathrm{TREN}]_{0}=60 / 1 / 0.2$, $9.0 \mathrm{~cm}$ of 20 gauge $\mathrm{Cu}(0)$ wire. The dotted line in expansion after thioeterification shows the original peak from before thioeterification, while 59 represents the increase in molar mass after thioeterification i.e., $2 *$ [SC6H5 (109, $2)-\operatorname{Br}(79,9)]=58.57$ for each chain end. 